\section{Piotr ZaWojski}

Instytut Nauk o Kulturze

Uniwersytet Śląski
Images

vol. XXX/no. 39

Poznań 2021

ISSN 1731-450x

\title{
A difficult history of light. About metaphysical ideas of "light writing" formulated before the birth of photography
}

\begin{abstract}
Zawojski Piotr, A difficult history of light. About metaphysical ideas of "light writing" formulated before the birth of photography. "Images" vol. XXX, no. 39. Poznań 2021. Adam Mickiewicz University Press. Pp. 281-295. ISSN 1731-450X. DOI 10.14746/i.2021.39.14.

The reflections presented in this article are devoted to Junko Theresa Mikuriyas book, A History of Light. The Idea of Photography. It is a unique view on the search for pre-photographic origins of photography in the field of philosophical writings ranging from Plato, through the neoplatonic philosopher Jamblich's enquiry, to the texts by Philotheus of Batos and by an early Renaissance philosopher, Marsilio Ficino. When thinking about metaphysics present in (moving and still) images, one should not forget about the metaphysics of the image itself. The idea of photography - regardless of whether we are witnessing a fundamental change in an ontological transition from an analogue to a digital form of image recording - obliges us to discuss the "history of light", as this is what Mikuriya does. While locating the discussed concepts in the context of the history and theory of photography, as well as the archaeology of media, the author of this essay engages in a dialogue with Mikuriya and polemically discusses many of her hypotheses. Key concepts such as chalepon, photagogia, triton genos, phôteinographeisthai are analysed in order to indicate inspiring moments in the Mikuriya's reflections, but also a kind of interpretive abuse in the process of reading and analysing philosophical texts addressing the issues of light.
\end{abstract}

KeYwords: Junko Theresa Mikuriya, A History of Light. The Idea of Photography, "light writing", history of photography, metaphysics of the image, chalepon

Photography is difficult (chalepon). Elusive both theoretically and materially, it is often described as having no identity of its own. It is treacherous - at times it hides behind its object of depiction, other times concealing itself underneath its bedazzling technical splendour. Its apparent instability belies its generosity; its hospitality is such that its boundaries are porous and mutable, inviting the encroachment of others

Junko Theresa Mikuriya, A History of Light. The Idea of Photography

According to Jacques Derrida, the presence of the issue of light (and shadow) permeates, or perhaps even illuminates, Western metaphysics and, in fact, "the entire history of our philosophy is a photology." [1] To confirm this, somehow from a different perspective, Geoffrey

[1] K. Dick, A. Ziering Kofman, J. Derrida, Derrida:

Screenplay and Essays on the Film, Manchester 2005,

p. 36. 
Batchen refers to... photosynthesis which, in his opinion, is nothing more than "the organic world of light writing", which must lead to a radical conclusion that "there has never not been photography." [2] An observation by Eduardo Cadava can be included in the discussion:

There has never been a time without the photograph, without the residue and writing of light. If in the beginning we find the Word, this Word has always been a Word of light, the "let there be light" without which there would be no history.[3]

Photology would thus be a reflection and discussion (the Greek term logos derives from lego meaning "speaking") concerning the history of philosophy, as well as a philosophical discourse, respectively philosophising, but also a reflection on all issues related to the phenomenon of light (phōtós). So, are philosophy and light inextricably linked, or even condemned to each other's company? Writing the history of philosophy is, in a sense, writing the history of light, or, more precisely, pondering upon the systematically accumulating philosophical literature which has made light one of the fundamental problems of metaphysics, but also of philosophical mysticism. It is also possible to reverse this statement and say that writing the history of light is in a way an attempt to reconstruct the history of philosophical thought from its Greek origin, that is, from the prehistory of philosophical reflection in general.

Junko Theresa Mikuriya's book A History of Light. The Idea of Photography can be located in at least several essential areas of reflection on light and photography. The areas include philosophy, or more precisely - metaphysics, references to reflection on the history and theory of photography, and, last but not least, inclinations to perceive phenomena in the spirit of media archaeology, which may not be manifested directly but which are clearly present anyway. The book is not declarative; its author does not cite specific authors or concepts underlying such research. But if we treat it not through the prism of interpretations of, for example, Thomas Elsaesser, Erkki Huhtamo, Jussi Parikka, Friedrich Kittler or Siegfried Zielinski,[4] but through the prism of a tendency to seek "deep time" of photography as a supra-historical idea, then Mikuriya's work can be examined from this perspective. Anarchaeology, that is a constant process of discovering the New in the Old, a paleontological attitude which involves the search for alternative solutions to official beliefs and judgments perpetuated over years, discovering peculiarities in terms of vision and hearing these are the foundations of methodological and theoretical concepts of

[2] G. Batchen, Burning with Desire: The Conception of Photography, Cambridge, MA, - London 1999, p. 183.

[3] E. Cadava, Words of Light. Theses on the Photography of History, New Jersey 1997, p. 5.
[4] I refer to only one collective publication which includes opinions of many researchers representing different strategies and forms of research in the field of media archaeology. Cf: Media Archaeology. Approaches, Applications, and Implications, eds. E. Huhtamo, J. Parikka, Berkeley - LosAngeles - London 2011. 
practicing media archaeology formulated by Zielinski.[5] However, while the German researcher conducts his study both in the field of technique and technology, that is various media apparatuses as well as ideas and theories describing their functioning, Mikuriya narrows her research to the world of ideas, particularly the philosophical ones.

Why does she perform such a reductive cut? The attitude stems from her assumptions and critical evaluation of the foregoing achievements of historians and theorists of photography. She does not depreciate other researchers' studies, but she draws attention to some unexplored or insufficiently examined fields of philosophical reflection which focus on the issue of light and, consequently, on the idea of photography. It is worth mentioning at the very beginning that formulations frequently appearing in the book, such as "I would like to propose", "in some manner", "seems to" or a statement that „[t]hese instances of the photographic should not be considered metaphors but rather intimations of photography," [6] clearly suggest a hypothetical nature of her reflection, although, on the other hand, the reflection is firmly attached to texts cited and analysed in her book.

In order to outline the research forefield, several ways of writing about the history of photography which dominated in the past can be indicated. I will try to briefly present these "negative" reference points in order to better emphasise the uniqueness of Mikuriya's approach to the history of photography further in my essay. The first is the diachronic/ historical tracking of the development of photography as an artistic medium, combined with an indication of subsequent technological inventions affecting the transformation of the medium itself. Examples include works by Beaumont Newhall[7] or Helmut and Alison Gernsheim.[8] In this perspective, particular importance is given to a camera prefiguration, that is, to camera obscura. Its technical construction, a tool-like form, and not solely the speculative anticipation presented by Plato in the allegorical cave, gave rise to the development of photography as a dispositif, i.e. combining technology, optics and chemistry in order to create images of reality. In one of the most recent works devoted to the history of photography, Kaja Silverman writes: "The idea that photography means 'camera' and that the camera is an instrument for mastering the world, emerged early in the history of the so-called medium." [9] These words can be treated as the shortest summary of such attitudes in which the belief that it all began with the camera obscura prevails.

The other mode of describing the phenomenon of the photography development involves the type of reflection which is dominated

[5] Cf. S. Zielinski, Deep Time of the Media. Toward an Archaeology of Hearing and Seeing by Technical Media, Cambridge, MA, - London 2006.

[6] Cf. J.T. Mikuriya, op.cit., pp. 46, 108, 116, 121.

[7] B. Newhall, The History of Photography from 1839 to the Present Day, New York 1949.
[8] H.A. Gernsheim, The History of Photography from the Camera Obscura to the Beginning of the Modern Era, London 1969.

[9] K. Silverman, The Miracle of Analogy or The History of Photography, Part 1, Stanford 2015, p. 14. 
by thinking about the technological dimension of the photography functioning in the social, cultural and political environment. Such practices create a kind of reference field - photography is not treated here as a form of magical "emanation" but as the effect of work of technical apparatuses used for very specific purposes. Such a belief can be found in the writings by John Tagg, $[10]$ who was consistently developing a mode of reflection where attention was focused not on photography itself, but on its relations with new institutions emerging in the nineteenth century, including new methods of observation and surveillance, representation and regulations which transformed the ways in which industrial society had operated.

And, ultimately, the type of reflection represented by the above mentioned Geoffrey Batchen.[11] He himself distinguishes two trends in reflection on photography: formalistic searching for the essence of "photographicity" ("photography as such") and situating photography as well as each photograph in a certain context (which constitutes a postmodern counter-discourse to the first trend). Inspired by Derrida's analysis, Batchen tries to somewhat eliminate these two tendencies, bearing in mind that pairs of binary oppositions are essentially alleged contradictions, which resonates with Derrida's concept of différance. More important, however, is that Batchen presents his own theory concerning the origins and beginnings of photography, which, according to him, grew out of the "desire to photograph" from the late 18th and early 19th centuries. While creating a kind of photogramatology, he shifts the actual beginnings of the development of this medium by drawing attention to the activities of proto-photographers, adding that between 1790 and 1839, at least twenty people described the desire to record images on a photosensitive surface. As a result, the key question appears to be "why", rather than "how", photography came into being. Batchen relates the answer to the fundamental process of modernity formation, which is a reference to Michel Foucault's theories formulated in Orders of Things[12] and referring to the transition from classical to modern episteme. When they "perversely interwove", photography could be born as the fruit of the order of modernity formation whose manifestation is, inter alia, this new medium.

Such a very briefly outlined background makes it obvious that Mikuriya's proposals are definitely different and original. The search for original ideas in photography is based on reading philosophical literature and its interpretations which, it is worth noting, are often highly problematic. And this actually makes dealing with this book very

[10] Cf. J. Tagg, The Burden of Representation. Essays on Photographies and Histories, New York 1988; idem: The Disciplinary Frame. Photographic Truths and the Capture of Meaning, Minneapolis - London 2009.

[11] G. Batchen, op.cit. A precise list of pre-photographers mentioned below can be found in G. Batchen's other work - Each Wild Idea. Writing,
Photography, History, Cambridge, MA, - London 2002, p. 6. Beside Niépce, Talbot and Daguerre, there are many other, almost unknown, writers and experimenters expressing this "desire to photograph". [12] M. Foucault, Orders of Things. An Archaeology of the Human Science, London - New York 2002. 
interesting and discussion-provoking. Although the author presents her main thought as a thesis "that photography has always existed in Western thought, even before the advent of photography," [13] it should be considered rather as part of speculative considerations which, however, does not weaken their cognitive attractiveness. Elsewhere, the author notes that 'invisibility' of the medium is not equivalent to an absence; invisibility is its mode of operation" and "it confirms the argument of this book that photography is embedded in the roots of Western thought." [14]

It is important to remember, however, that the theme of light as a kind of central point around which visual media should be defined has often appeared in historical and theoretical considerations concerning pictorial phenomena. One of the perfect examples here could be Sean Cubitt's The Practice of Light. A Genealogy of Visual Technologies from Prints to Pixels, which was published a few years before Mikuriya's book; however, the latter author does not mention Cubitt's work, which is quite characteristic. Such omissions are common in Mikuriya's work; this is obviously not an allegation, as they point to a particular narrowing of the field of bibliographic and reading references, where works highlighting the importance of physical media and the technological dimension of image creation are consistently excluded. Cubitt treats media as physical processes - matter, energy and form - but also tools of communication and mediation.

Light is such a mediation not only between people but also between human and non-human worlds. Light fills and forms the world. For millennia light from the sun and the celestial bodies, and from burning organic matter derived from sunlight, spilled with the seemingly boundless generosity of a god or gods into the human universe.[15]

Let us therefore look at how Mikuriya, following the arguments of Plato, Jamblich, Philotheus of Batos and Marsilio Ficino, reconstructs the threads concerning light from their writings and how the writings make it possible to justify the concept that the idea of photography is not only older than the tools used for its production, but appears as early as in ancient philosophical texts. Although her reflections refer to many concepts, I will present the most important ones which form a kind of grid, or a theoretical foundation, for developing her own interpretation of the idea of photography based on the interpretation of the source texts. My analysis will include the following key concepts: photagogia ("absorbing of light", "experiencing light"), chalepon ("difficulty"), chora

[13] J.T. Mikuriya, op.cit., p. 8.

[14] Ibidem, p. 49.

[15] S. Cubitt, The Practice of Light. A Genealogy of Visual Technologies from Prints to Pixels, Cambridge, MA, - London 2014, p. 2. Marianna Michałowska also draws attention to the reflections on light in the context of "reformulating the definition of media" in her in-depth review of Mikuriya’s book. Cf. M. Michałowska, Sokrates patrzy w słońce, „Przegląd Kulturoznawczy" 2019, no. 3 (41), pp. 403-409. Cubitt's book is developed and complemented by a collective work on "digital light". Cf. Digital Light, eds. S. Cubitt, D. Palmer, N. Weaven, London 2015. 
(a concept that is not clearly defined, this is both a place and a nonplace, something that is formless and, at the same time, takes up every form, it is this and that, present and absent), triton genos ("third kind"). A separate place in this set is occupied by the term photeinographeisthai, a verb meaning as much as: "to photograph" (in other words it is "light writing"). To this day, there are disputes about who was the first to use the term "photography", created as a combination of Greek phötos and graphé; for a long time, authorship was ascribed to John Herschel (1839). However, in the late 1970s, Brazilian photographer and researcher of the history of photography Boris Kossoy proved that in Brazil, completely independently to the events occurring in Europe, Hercules Florence, a painter and inventor, not only developed a negative-positive method but also, in 1834, used the French term photographie in his notes. [16] It is a relatively little-known but an extremely interesting story which sheds a whole new light (nomen omen) on the beginnings of photography and once again proves that the Eurocentric point of view on media history has often led to false diagnoses being now verified by media archaeology.

Before I proceed to the aforementioned keywords, I would like to discuss the concept of photeinographeisthai, because its origin can tell us a lot about the beginnings of the idea of photography. Its creator was the monk Philotheus of Sinai (also called Philotheus of Batos), about whom almost nothing is known except for the fact that he lived in the 9th or 1oth century and wrote a work entitled Forty Texts on Watchfulness, later incorporated by St. Nicodimos of the Holy Mountain and St. Makarios of Corinthc into The Philokalia - a collection of writings by Eastern Orthodox Church mystics of the hesychast school of spirituality. Unfortunately, the passage on "light writing" cannot be found in the English edition of Forty Texts on Watchfulness. [17] I base the information about the fragment on Georges Didi-Huberman's essay Celui qui inventa le verbe "photographier" (The Man who Invented the Verb "to Photograph"), which Mikuriya also refers to. So, this important discovery was made by a Frenchman; unfortunately I am unable to determine whether he used the Greek original (the first edition of The Philokalia was published in 1792 in Venice) or other sources while writing his essay. To the best of my knowledge, the French translation did not exist at that time. Didi-Huberman wrote:

Today we no longer know where the scarp in Sinai was on which Philotheus of Batos opened his eyes wide to the sun and imagined the verb "photograph". We do not know the incomprehensible name which was interrupting his ravenous vision and breathing. All we know is that the verb "to photograph" came there, under his tongue, not so much as pleasure (plaisir) derived from images and forms of reality, but as infinite ecstasy

[16] B. Kossoy, Hercules Florence, Pioneer of Photography in Brazil, "Image. Journal of Photography and Motion Pictures of the International Museum of Photography at George Eastman House" 1977, vol. 20, no. 1.
[17] Cf. The Philokalia. The Complete Text Compiled by St Nikodimos of the Holy Mountain i St Makarios of Corinthc. vol. 3, transl. and eds. by G.E.H. Palmer, P. Sherrard, K. Ware, London 1984. 
(jouissance) of an amorphous image. The pure tactile intensity which light fluctuates on our face with - a face viewed by the light as if by a mother feeding a newborn. [18]

How did it happen that it was the meditating and praying Philotheus who created the term "to photograph"? His meditations were based on a mystical school of in-person prayer which consists in maintaining inner balance and peace by means of napsis, that is, vigilance combined with a prayer whose rhythm is adjusted to breathing. Immobility and psychosomatic technique of staring at one's own navel (because this is supposedly the place occupied by the soul), all this was to contribute to the search for transcendent light, that is, to see the Light of God and to be united with God, and, consequently, to become a pure image and to abandon one's body. This process can be interrupted by images which one may call ordinary images. While commenting on Didi-Huberman's reflection, Pierre Taminiaux in The Paradox of Photography notes that Philotheus was not attracted by

the creation of finite and visible objects. To the contrary, Philothée was highly suspicious of the power of images. He intended to chase them instead. Paradoxically, this negation (or disappearance) of images was only made possible through the presence of pure light internally and externally. The experience of light ultimately defined the profound and almost overwhelming sensation of a "pure tactile intensity." [19]

To see God and to be seen by God, to see and to be seen are equivalent phenomena; to see the light and to be "photographed" by it is the path to become the light you contemplate yourself - this is how the metaphysics of light, available only to the chosen, are revealed. Mikuriya asks an important question in this context: "And what are its implications for the history of photography, if we consider that the word we would later come to know as "photography» was in fact invented by a mystic?" [20] The mystical sources of reflection on the issue of light and photography must lead to the conclusion that, actually, the idea of "light writing" has a great interpretive potential and forces us to ask questions not only in the field of technique and technology, but, above all, of philosophy and metaphysics of image(s). Most often, when images (static or moving, the latter being impossible without the first ones, just like in films based on a traditional photosensitive medium) were discussed in the past, the focus was on metaphysics present in images, on transcendence as an element transgressing possibilities of human understanding, something that exists beyond the reality available to the senses and operational capabilities of the human mind. This was

[18] G. Didi-Huberman, Celui qui inventa le verbe "photographier", [in:] idem: Phasmes. Essais sur L'Apparition, Paris 1998, pp. 55-56. A rather non-accidental usage of the terms plaisir and jouissance, which must be immediately associated with Barthesian interpretation of these terms, should be indicated here. Cf. R. Barthes, The Pleasure of the Text, New York 1975.

[19] P. Taminiaux, The Paradox of Photography, Amsterdam - New York 2009, p. 132.

[20] J.T. Mikuriya, op.cit., p. 83. 
reflected in many outstanding filmmakers' deeds, but also in photographic works.

Less often, however, the discussions dealt with the metaphysics of the image itself, with its mysterious nature which eludes not only an unambiguous, but actually any at all, attempt to be defined. In this sense, every image can be described as transcendent, going beyond all boundaries, like in the case of photographic image and photography as a medium, which, by using light for imaging, triggers well-known and today technologically understandable processes in order to finally create something that we have been struggling with for centuries. The image remains a mystery requiring explanation. That is why the attempts to unravel it, the hard work aimed at illuminating the darkness surrounding the images, are so fascinating. In traditional photography, the process of creating images begins with light (projected on a photosensitive material), then it moves towards darkness (a negative form of the image) and ultimately back to light, in the form of a positive image - a photograph/photo which presents an already visible (in full light) image.

It is worth adding that in 2019, Italian photographer Nicolai Ciannamea, inspired by Georges Didi-Huberman's essay, created a series of photographs entitled Il verbo Fotografare, presented at the exhibition Viandanti a Sud organised by Museo Pino Pascali in Polignano, Italy. According to the artist himself, the photographs taken near the shrine of Madonna della Scala in Massafra, Taranto Province and in Masseria San Marco di Fasano present caves which were excavated for people to live in, pray and defend themselves. These caves used to be houses, shops and churches, but, in his opinion, they resemble eyes directed towards light.[21] I can only add that it is also impossible not to associate these caves with the one described by Plato in Republic, the cave Junko Theresa Mikuriya begins the essential part of her book with. Let us go back now to the aforementioned key terms in order to present Mikuriya's concepts more broadly.

The statement that writing about photography has been difficult is a truism. But this difficulty has different degrees and reference points. A History of Light is not about the difficulty for many years faced by all those who have taken up the issues referring to, for instance, defining photography, which Mikuriya does not actually deal with, treating it is an essentially unproductive task because the versatile nature of photography results in not only terminological but also material and conceptual instability. Chalepon (meaning not only something difficult, but also dangerous and troublesome) derived from Plato's writings ( $R e$ public and Timaeus), becomes a kind of spell for Mikuriya. In moments of doubts concerning, for example, the beginnings of photography, the spell can be used to protect the author from being accused of lack of 
precision or of over-interpretation. Especially when the author goes so far as to state

that Socrates is in fact functioning as a photographer who captures and fixes images $[\ldots]$. This first photograph taken by Socrates would probably resemble a negative image, all darkness except for the areas lit by the single light source inside the cave. What we see in the photograph are shadows, the shadows on the walls, the silhouettes of the inhabitants, the hazy outlines of the puppeteers and the dancing firelight.[22]

Undoubtedly, defining photography is difficult, but it is also truly hard to accept this kind of adjustment of certain opinions to one's own statements. Mikuriya recalls a sentence taken out of a broader context; its author, James Elkins, when asked about the cause of difficulties in conceptualising photography, answered that "One immediate reason is that it is not one subject, but several." [23] Therefore, doubts are raised as to why she does not even try to combine her readings of philosophical literature with the prospect of studying material sources that shape fundamental philosophical ideas. It is not even a question of the relationship between creation of certain ideas and their media embodiment, but of an attempt to transgress a self-limiting discourse consisting in a more or less fortunate analysis of terms, which often seems to be a mere speculation, or perhaps a voluntary over-interpretation. I do not deny that it is sometimes intellectually stimulating and thought-appealing, but too often it transforms into a kind of far-reaching hypothetical judgements. Or perhaps, this might be the value of philosophising, also on photography, which makes the play with concepts encouraging for thought and reinterpretation, a kind of remix of the beliefs established and preserved over the years in the discourse of photographic experts.

The subsequent keywords are Platonic chora and triton genos. The literature discussing the first concept in particular is as impressive as it is not easily digestible; it is enough to mention the writings of Martin Heidegger, Julia Kristeva or Jaques Lacan. In the basic sense, chora means a rural territory surrounding an ancient polis, located outside a city. But this definitely does not exhaust the subject of chora, which in Plato's works is presented as triton genos, the "third kind", and in Mikuriya's reflections it can be understood as photography. To demonstrate this, the author refers to perhaps the most famous deconstructive interpretation of chora presented by Jacques Derrida. The following passage quoted by Mikuriya proves that it can be successfully applied to photography:

Khôra receives, so as to give place to them, all the determinations, but she/ it does not possess any of them as her/its own. She possesses them, she has them, since she receives them, but she does not possess them as properties, she does not possess anything as her own. She "is" nothing other than the sum or the process of what has just been inscribed "on" her, on the subject 
of her, on her subject, right up against her subject, but she is not the subject or the present support of all these interpretations, even though, nevertheless, she is not reducible to them.[24]

Mikuriya even claims that these words can be "easily" applied to photography, and undoubtedly her ingenuity at this point deserves attention; this type of extrapolation is, of course, a controversial procedure, but at the same time an intellectually attractive one. Chora has strange properties; it is a perfect example of an "indeterminate" concept reminiscent of other "indeterminancies", such as pharmakon or parergon. Chora is neither present nor absent, neither good nor evil, neither alive nor inanimate, it lacks even an elementary identity, it does not fit into the logic of 'either-or' because it is what it is not at the same time. As Derrida says while reading Plato's Timaeus and trying to explain (something essentially unexplainable): "One cannot even say of it that it is neither this nor that or that it is both this and that. It is not enough to recall that khōra names neither this nor that, or, that khōra says this and that." [25]

The reason why photography is difficult (chalepon), according to the author of A History of Light, lies in its nature, which resembles that of chora; therefore, it belongs to the category of triton genos. Being an indefinable "third kind", it should be identified with light, the latter lying at the heart of the ongoing discussion regarding photography. However, it is understood not as a medium, or a tool for preserving images of reality on a medium, but as an idea going far beyond materiality, functioning in the space of thought and not a physical one, existing beyond material things, beyond any forms of recording, although it consists in light writing. Such an adaptation of Platonic concepts to the analysis of the idea of photography is attractive and questionable at the same time; travestying Derrida (who travestied Plato), it can be said that it is both this and that without being at the same time this or that. Remaining in this convention of a linguistic game but also of my assessment of Mikuriya's ideas, I may declare that I both agree and disagree with her hypotheses; I accept them, but simultaneously, I consider them to be the evidence of interpretive abuses and too far-fetched suppositions.

And finally, we come to photagogia, meaning "absorbing the light", the last of the keywords, though it would undoubtedly be possible to add others to this necessarily concise set of the most crucial terms. It was described by Iamblichus, a Neoplatonic philosopher living in the 3rd century BC, in the treaty De Mysteriis. Photagogia, in which the term is also translated as "evoking of light" or "leading of light". The author once again performs a brilliant analysis of the philosopher's writings and extracts from them mainly threads related to light. Photagogia, according to Iamblichus, is closely connected with theurgy, or ritual practices mostly of a magical nature, aimed at getting closer to 
divinity. They are far more important than the intellectual reflection, as the author notes, "For Iamblichus, it is theurgy and not philosophy that possesses salvific possibilities." [26]

This ritualistic dimension of the theurgic activities is to serve religious practices, unlike in the case of magic - even if the latter uses religious formulas, they serve secular purposes. Photagogia is close to photography because it uses light, through theurgic activities one can move towards divinity by absorbing light, opening up to its absorption. After all, this is how a photo camera works: by absorbing light which reacts with a photosensitive material, it records/writes images. In fact, it is not about an image but about a metaphysical experience of communing with the pure phenomenon of light. Just like an iconographer writes icons [27], light can "expose" a man who wants to meld with the essence of divinity identified with light. It is a kind of illumination, enlightenment (in various meanings of the word), a theurgist is transformed into "a 'container' for light" [28], they become a camera in which, owing to light, the process of producing an image - a photography takes place. It should be emphatically repeated that the image is here secondary, the metaphysics of the image as a phenomenon transgressing human senses gives way to the very act of experiencing something which exceeds the possibilities of rational explanation. Mikuriya concludes:

I suggest that Iamblichean theurgy is the site where one sees a re-emergence of chora as photography. In the theurgist's encounter with the divine, his soul is transformed into a camera which captures the light emanating from the deities.[29]

In one of the subsequent chapters, Mikuriya presents yet another understanding of photagogia, which she encountered in several texts by a Renaissance philosopher, Marsilio Ficino. With this part, she concludes her fundamental considerations, followed only by Coda, the latter being discussed later in this article. She therefore closes her peregrinations by discussing works created during the early Renaissance (Ficino lived in the years 1433-1499), the period which is referred to by many scholars who search for "archaeological" origins of photography associated with popularisation of camera obscura. This is, for example, an experiment by Filippo Brunelleschi, who depicted the Florence baptistery of San Giovanni using the Cathedral of Santa Maria del Fiore as

[26] Ibidem, p. 61.

[27] Although there are experts - such as a prominent icon connoisseur, Henryk Paprocki - who argue that the term "writing icons" is inappropriate. "[...] I personally don't like the phrase «icon writer» as I find it absurd [...]. In Polish using the word «to write» in reference to painting is an obvious Russianism from the word pisat' (писа́ть). In Russian, if we use the word pisat', it refers not only to icons. We say pisat' kartinu (писа́ть kартину) meaning «to paint a picture»: you can pisat' akt (писа́ть акт) - paint a nude, pisat' pejzaż (писа́ть пейзаж) - paint a landscape, and here writing does not mean any activity different from regular painting". Ks. Henryk Paprocki: Ikona Nowosielskiego przetrwa jako żywa sztuka. Z ks. Henrykiem Paprockim rozmawiał Karol Grabias, h<ttps://teologiapolityczna.pl/ks-prof-henryk-paprocki-ikona-nowosielskiego-przetrwa-jako-zywa-sztuka>, accessed: 4.11.2020.

[28] J.T. Mikuriya, op.cit., p. 76.

[29] Ibidem, p. 81. 
a kind of camera obscura, or Leonardo da Vinci's interest in this invention. This passage focuses on different variants of "photosensitivity" and how "Ficino may in fact be intimating the advent of photography." [30] The method of assumptions and bold comparisons in these passages reaches a disturbing level, and once again it should be concluded that this type of reading of philosophical texts susceptible to various interpretations evoked my strong objection at times. To illustrate this, I will quote a longer passage, in which the author first quotes Ficino, and then - with one definite (?) sentence - reiterates the philosopher's view:

For it is probably that, if images have any power, they do not so much acquire it just at the moment of receiving a figure as possess it through a material naturally so disposed; but if an image eventually acquired something when it was engraved, it obtained it not so much through the figure as through the heating produced by hammering. This hammering and heating, if it happens under a harmony similar to that celestial harmony which had once infused power into the material, activates this power and strengthens it as blowing strengthens a flame and makes manifest what was latent before, as the heat of a fire brings to visibility letters previously hidden which were written with the juice of an onion; and as letters written with the fat of a goat on a stone, absolutely unseen, if the stone is submerged in vinegar, emerge and stick out as if they were sculptured. So much Ficino, and now Mikuriya: As we can see, the notion of a chemical photosensitivity is brought to the forefront in this passage.[31]

Yes, "basically" it resembles chemical photosensitivity, but can this "reminder" be actually treated seriously? The similar applies to the statement that the human body's particular sensitivity to light is, according to Ficino, supposed to result in transformation of the human soul into the photo camera.

His very interesting book on the relationship between photography and dialectical concepts present in the works of Walter Benjamin, Georg Wilhelm Friedrich Hegel and Jacques Derrida - Dag Petterson begins with the words uttered by the French thinker: "The philosopher should start by meditating on photography, that is to say the writing of light before setting out towards a reflection on an impossible self-portrait." [32] In Coda, Mikuriya again indicates the source of her methodological and theoretical inspirations which are undoubtedly deconstructive modes of reading philosophical texts under the patronage of Derrida. She focused her attention on photography as a source of Western metaphysics, stressing that these references are not metaphors, they rather express her "intuitions". Does she create her own philosophical self-portrait in this way? Is it really possible to create it?

[30] Ibidem, p. 107.

[31] Ibidem, p. 116.

[32] D. Pettersen, The Art of Reconciliation. Photography and the Conception of Dialectics in Benjamin, Hegel, and Derrida, London 2013, p. VIII. This quote comes from an extraordinary book, actually an album by Steve Pyke, which includes photographic portraits of eminent contemporary philosophers completed by citations from their writings. Cf. S. Pyke, Philosophers, London 1995. The project was continued in the second volume. Cf. S. Pyke, Philosophers, New York 2011. 
It is just as problematic as the question of credibility of a photographic portrait which is a way of perpetuating and memorising images of a person, but it can also be treated as a form of a counter-memory, as Roland Barthes was well aware.[33] Franz Kafka addressed the topic of photography with disapproval during conversations with his friend Gustav Janouch. "Nothing can be so deceiving as a photograph", he used to say, adding, "We photograph things in order to drive them out of our minds. My stories are a kind of closing one's eyes." [34] According to him, the camera obscures a hidden life rather than brings it to the surface, even though it uses light. One could add that photography brings things down into the dark. Franz Kafka, of course, was not isolated in his views. A long list could be made of, for example, painters who thought that it is the last attribute of a photograph, and more broadly photography, to truly represent the captured object.

However, let us give up this thread and return to Coda, and more specifically, to Jacques Derrida's book Athens, Still Remains which is an aphoristic commentary on a series of thirty-four photographs by Jean-Françoise Bonhomme, depicting both modern Athens and the ruins of this ancient city. In his youth, the artist attended the Paris film school, and later, he studied philosophy under the supervision of Gilles Deleuze and Jean-François Lyotard, and participated in seminars by Roland Barthes and Michel Foucault. It is not surprising that he took up philosophical threads in his photographic practice. Derrida, when writing about Bonhomme's works, once again implicitly returns to the reflection on ancient philosophers (Plato, Socrates) while creating his own interpretation of the photographic medium. As Mikuriya writes, "The imminence of death, its inevitability and its momentary suspensions are considered photographic by Derrida." [35] It is also Derrida's recollection of his stay on the headland of Cape Sounion during his trip to Greece, when, looking out to sea, he imagined the portrait of Socrates: "I would thus have photographed Socrates awaiting death." [36] Once again, in the theoretical reflection on photography, an association with death appears. The photagogic dimension of photography consisting in absorbing light is close to eternal darkness, to an imminent death, at the same time. Although it is true that "[e]very photograph is of the sun," [37] it was the dialectics of light and darkness that for years used to set the logic of photograph creation. Today, in the age of the actual dominance of digital photography, this dialectics is suspended; light coming through the lens into the camera no longer operates on a photosensitive material in a "dark chamber", it is subjected to the operational action of mathematical algorithms managing digital sensors. Have we thus come to the end of the history of light, or just to the end

[33] R. Barthes, Camera Lucida. Reflections on Photography, New York 1981, p. 91.

[34] G. Janouch, Conversation with Kafka, New York 2011, (Kindle), no pagination.
[35] J.T. Mikuriya, op.cit., p. 122.

[36] J. Derrida, Athens, Still Remains. The Photographs of Jean-François Bonhomme, New York 2010, p. 29.

[37] Ibidem, p. 65. 
of traditional photography? In this point, I will for the last time quote the author of A History of Light, who asks a provocative question and presents her assumptions again:

Does Demeure, Athènes [it is the French title of Derrida's book - P.Z.] mark the end of analogue photography? Perhaps we can view the two models of photagogia - the continual drawing down of light and the sudden burst of light - as exemplifying the differences between continuity and interruption, analogue and digital.[38]

I would be happy to read further reflections on the second model of photagogia suggested here. But is it possible to subject digital photography, which actually deals with light as well, to this kind of analysis? Or can the theoretical proposals presented here be simply extrapolated to it? I leave these questions unanswered.

Reading this book was a difficult (chalepon) experience, but I do not consider it worthless; it undoubtedly allowed me to look at photography from an unprecedented point of view, which in itself significantly compensated for the hardships of reading. For the purpose of this article, the variety of threads had to be confined to the analysis of only several basic notions; therefore, it does not fully reflect the erudition and ingenuity of the exegetic author reading the philosophers of light.

Barthes R., Camera Lucida. Reflections on Photography, New York 1981

Barthes R., The Pleasure of the Text, New York 1975

Batchen G., Burning with Desire: The Conception of Photography, Cambridge, MA, London 1999

Batchen G., Each Wild Idea. Writing, Photography, History, Cambridge, MA, London 2002

Cadava E., Words of Light. Theses on the Photography of History, New Jersey 1997

Cubitt S., The Practice of Light. A Genealogy of Visual Technologies from Prints to Pixels, Cambridge, MA, - London 2014

Derrida J., Athens, Still Remains. The Photographs of Jean-François Bonhomme, New York 2010

Derrida J., Khôra, [in:] J. Derrida, On the Name, Stanford 1995

Dick K., Ziering Kofman A., Derrida J., Derrida: Screenplay and Essays on the Film, Manchester 2005

Didi-Huberman G., Celui qui inventa le verbe „photographier”, [in:] G. Didi-Huberman, Phasmes. Essais sur L'Apparition, Paris 1998

Digital Light, eds. S. Cubitt, D. Palmer, N. Tkacz, London 2015

Foucault M., Orders of Things. An Archaeology of the Human Science, London New York 2002

Gernsheim H.A., The History of Photography from the Camera Obscura to the Beginning of the Modern Era, London 1969

Janouch G., Conversation with Kafka, New York 2011 
Kossoy B., Hercules Florence, Pioneer of Photography in Brazil, „Image. Journal of Photography and Motion Pictures of the International Museum of Photography at George Eastman House", 1977 vol. 20, no. 1

Ks. Henryk Paprocki: Ikona Nowosielskiego przetrwa jako żywa sztuka. Z ks. Henrykiem Paprockim rozmawiał Karol Grabias, <https://teologiapolityczna.pl/ ks-prof-henryk-paprocki-ikona-nowosielskiego-przetrwa-jako-zywa-sztuka> accessed: 4.11.2020

Media Archaeology. Approaches, Applications, and Implications, red. E. Huhtamo, J. Parikka, Berkeley - Los Angeles - London 2011

Michałowska M., Sokrates patrzy w słońce, „Przegląd Kulturoznawczy” 2019, nr 3 (41)

Mikuriya J.T., A History of Light. The Idea of Photography, London 2016

Newhall B., The History of Photography from 1839 to the Present Day, New York 1949

Pettersen D., The Art of Reconciliation. Photography and the Conception of Dialectics in Benjamin, Hegel, and Derrida, London 2013

Photographic Theory, ed. J. Elkins, New York - London 2007

Pyke S., Philosophers, London 1995

Pyke S., Philosophers, New York 2011

Silverman K., The Miracle of Analogy or The History of Photography, Part 1, Stanford 2015

Tagg J., The Burden of Representation. Essays on Photographies and Histories, New York 1988

Tagg J., The Disciplinary Frame. Photographic Truths and the Capture of Meaning, Minneapolis - London 2009

Taminiaux P., The Paradox of Photography, Amsterdam - New York 2009

The Philokalia. The Complete Text Compiled by St Nikodimos of the Holy Mountain i St Makarios of Corinthc. vol. 3, trance. and ed. by G.E.H. Palmer, P. Sherrard, K. Ware, London 1984

Zielinski S., Deep Time of the Media. Toward an Archaeology of Hearing and Seeing by Technical Media, Cambridge, MA, - London 2006 